\title{
RESOLUTIONS ADOPTED AT THE ANNUAL MEETING, OCTOBER, 1950
}

1. WHEREAS all sound silviculture rests on a knowledge of soils and sites; and

WHEREAS there is a need for the definition of problems and the interchange of ideas by foresters working in these fields; therefore

BE IT RESOLVED that a Committee on Forest Soils and Sites be established by the Canadian Institute of Forestry.

2. Whereas, a resolution approved at the Annual Meeting in 1949, dealing with the study of land tenure and taxation, instructed the General Executive to request all sections to make special studies of these subjects during the current year, AND WHEREAS, it is felt that these studies are still far from complete; therefore

BE IT RESOLVED that the General Executive of the Institute set up a special Committee on Land Tenure and Taxation to co-ordinate the work of the secion committees in carrying out the purpose involved in the resolution of 1949 to wit:

"(a) Systems of tenure of forest land in Canada, the United States, and any other countries whose experience may be deemed useful, with a view to discovering the merits and demerits of each.

(b) The scientific principles of assessment and taxation which apply to forest properties, to determine the rightful amount which such properties should contribute to the public revenues.

(c) Systems of public control of operations on forest properties by private owners, lessees, etc., in use in Canada and other countries."

3. Whereas the Canada Forestry Act was passed in the year 1949; and

WHEREAS this body, then known as the Canadian Society of Forest Engineers, at its annual meeting in Toronto in October, 1949, passed a resolution commending the action of the Minister of Mines and Resources; and

WHEREAS the Minister of Resources and Development has announced that he has invited the Provinces to express their views as to how the Canada Forestry Act may best be implemented;

AND WHEREAS the Canadian Institute of Forestry is not aware that any suggestions made by the Provinces have been acted upon,

BE IT RESOLVED that this Institute of Forestry wishes the Minister to expend every effort to complete an arrangement at the earliest possible date with any Provinces having made suggestions approved by the technical staffs of the Governments concerned.

AND FURTHER to organize an increase in the protection of forest lands which belong exclusively to the Government of Canada.

4. RESOLVED that the Executive of the Canadian Institute of Forestry be instructed to send a letter of congratulation to the Canadian Forestry Association on the attainment of their Soth Anniversary.

5. Whereas the woodlots of Canada are the most accessible and potentially the most productive forest areas, and 
WHEREAS their wood production and their other values affect a large proportion of Canadians, and WHEREAS these woodlots are now, for the most part, poorly protected and cut destractively, therefore

BE IT RESOLVED that, to call greater attention to this problem and to undertake more effective action, the Canadian Institute of Forestry, during 1951, will concentrate its efforts, as fully as possible, on promotion of woodlot management in Canada, and

Be It Further Resolved that the Standing Committee on Woodlot Management establishes for 1951 a Woodlot Management Promotion Committee, to facilitate the required co-operative, co-ordinated effort.

\section{Personalia}

\section{NEWS OF THE SECTIONS}

QUEBEC

Dr. Pierre Dansereau, whose interesting talks have enlivened many of our Section meetings, has been appointed to the staff of the Department of Botany, University of Michigan, Ann Arbor, Michigan.

We wish him every success and happiness in his new position.

Contributed by W. D. BENNETT.

Meetings

\section{Central Ontario}

Attendance at the meeting of the Central Ontario Section, Canadian Society of Forest Engineers, in Sudbury on Saturday, September 23rd, set a record with 46 present. The business dealt with reports on progress for the Annual Meeting of the Society. C. A. Rowe, Chairman of the Committee, reported that preparations were well advanced.

The chief topic for discussion was the Mississagi Salvage Operation. Ross Hyslop, of the Department of Lands \& Forests, Sault Ste. Marie, covered the logging end of the subject; Don Milne, of the Great Northern Woods Company, North Bay, explained the method of marketing the salvage lumber; and Dr. M. L. Prebble and L. M. Gardiner, of the Forest Insect Laboratory, Sault Ste. Marie, pointed out the effects of insect infestation on the burned timber. It was shown that the work of the Forest Insect Laboratory had played a major part in determining the methods by which the salvage operation was carried out.

$M r$, and Mrs. B. F. Merwin entertained the members, their wives and friends, at their residence and later at a buffet dinner at the Idylwylde Golf Club. Mr. Mutz, of the International Nickel Company, Mr. MacKay and $M r$. Morrison of the Department of Lands \& Forests, Toronto, and Dr. Prebble, Officer-in-charge, Forest Insect Laboratory, spoke briefly. The Honourable Mr. Gemmell, Minister of Mines for Ontario, was the guest speaker. His talk was built around the close tie between the mining and forest industries in Ontario. 